\section{The improving quality of research by hospital pharmacists bodes well for the future}

Philip Wiffen

This editorial is to announce the second 'on-line only' issue published by EJHP at the time of the EAHP Congress 2020 (now postponed due to coronavirus). In recent years we have seen an encouraging growth in both the number of submissions to EJHP and also in the quality of those submissions. This bodes well for the future of research by hospital pharmacists. The flip side of this development is that it can take up to 12 months for an accepted

Correspondence to Professor Philip Wiffen, Pain Research Unit, Churchill Hospital, Oxford OX3 7LE, UK; pwiffen@oxfordsrs.org.uk paper to appear in print due to the fixed number of pages per issue.

This 'on-line only' edition includes some 18 papers mostly related to pharmacokinetic studies and stability studies. These have been selected because they contain useful reference material that will be relevant to subgroup of hospital pharmacists. The advantage for authors is that their papers not only appear in a special addition but also these papers will be made 'free to view' for 12 months from the issue launch. This will make their data available worldwide to all and potentially increase citations for these papers. On the other hand, these papers will not be included in a print issue.

I hope many international pharmacists will find this issue useful in their practice

Funding The authors have not declared a specific grant for this research from any funding agency in the public, commercial or not-for-profit sectors.

Competing interests None declared.

Provenance and peer review Commissioned; internally peer reviewed.

(c) European Association of Hospital Pharmacists 2020. No commercial re-use. See rights and permissions. Published by BMJ.

A) Check for updates

To cite Wiffen P. Eur J Hosp Pharm 2020;27:e1.

Eur J Hosp Pharm 2020;27:e1.

doi:10.1136/ejhpharm-2020-002280

ORCID iD

Philip Wiffen http://orcid.org/0000-0001-6085-1307 